Gut, 1985, 26, 1053-1058

\title{
Elution of cytomegalovirus antibodies from adenocarcinoma of the colon
}

\author{
ANN GRAIL AND MARY NORVAL \\ From the Department of Bacteriology, University of Edinburgh Medical School, Edinburgh
}

SUMMARY Eluates were prepared by high salt extraction from normal colonic mucosa and adenocarcinomatous tissue from 28 patients, eight more from unmatched colonic tissue and five from patients with other gastrointestinal disease. Immunoglobulins were detected by ELISA: IgG was present in $24 \%$ eluates from normal colon and $21 \%$ from carcinomas; IgA in $55 \%$ eluates from normal colon and 39\% from carcinomas; IgM in 55\% from normal colon and 37\% from carcinomas. Cytomegalovirus-specific antibody was found in $15 \%$ eluates from normal colon and in $18 \%$ carcinomas. Out of the 28 matched specimens, cytomegalovirus-specific IgG was detected in one normal and four tumour eluates, specific IgA in two normal and four tumour eluates, and specific IgM in two normal and two tumour eluates. In two instances cytomegalovirus-specific antibody was present in the eluates prepared from the normal and tumour tissue of the same patient. Of those eluates which contained cytomegalovirus-specific antibodies by ELISA, two were positive by anti-complement immunofluorescence of human embryo fibroblasts infected with cytomegalovirus strain AD-169. It seems possible, therefore, that cytomegalovirus antigens on colonic cells may be masked by complexing with anticytomegalovirus antibodies, and may not therefore be detected by techniques such as immunofluorescence.

Most cytomegalovirus infections of man are asymptomatic although they can occasionally result in congenital defects, infectious mononucleosis, interstitial pneumonia, hepatitis, and other severe diseases. ${ }^{1}$ After the primary infection, the virus persists in the body by unknown mechanisms and in unknown sites, although peripheral blood leucocytes seem to represent one cell population from which virus can be recovered on occasion.

There has been suggestive evidence that cytomegalovirus may be involved in the pathogenesis of certain types of cancer, particularly Kaposi's sarco$\mathrm{ma}^{2}{ }^{2}$ carcinoma of the cervix ${ }^{3}$ and prostate,${ }^{4}$ and adenocarcinoma of the colon. Thus in 1978 Huang and Roche ${ }^{5}$ detected cytomegalovirus-DNA by hybridisation in four of seven patients with carcinoma of the colon, while Hashiro and coworkers ${ }^{6}$ isolated cytomegalovirus from cultured tumour fragments in three of eight cases. More recently, however, Brichacek and others ${ }^{7}$ failed to detect

Address for correspondence: Dr A Grail, Department of Bacteriology, University of Edinburgh Medical School, Teviot Place, Edinburgh EH8 9AG.

Received for publication 22 November 1984 cytomegalovirus DNA, using DNA-DNA hybridisation with an estimated sensitivity of 0.3 genome equivalents per cell, in biopsy specimens from seven patients with colonic carcinoma. In addition we failed to confirm an involvement of cytomegalovirus using hybridisation, immunofluorescence to detect cytomegalovirus-specific antigens, and by culture of biopsy specimens. ${ }^{8}$ Roche et al $l^{9}$ have looked again at the role of cytomegalovirus in gastrointestinal disease and concluded that the virus was detectable by DNA-reassociation kinetics in a proportion of colonic cells, including those derived from both malignant and non-malignant tissue. It was suggested that cytomegalovirus was present in masked or latent form, and no biopsy specimens were positive for viral antigens by immunofluorescence. It is possible that such antigens on the surface of tumour cells could be blocked by complexing with antibodies as has been suggested recently. ${ }^{10}$ Indeed just such a situation has been described for Herpes simplex virus-specific antibodies in squamous cell carcinoma of the uterine cervix in the absence of apparent infection of the tumour cells by the virus. ${ }^{11}$

Thus the present study was undertaken to identify 
bound immunoglobulins in normal and adenocarcinomatous colonic mucosa, and to identify whether any was cytomegalovirus specific.

\section{Methods}

\section{CLINICAL SPECIMENS}

Surgically resected specimens of colon were obtained from the Royal Infirmary, Edinburgh. Diagnosis and Duke's stage, where appropriate, was based on routine pathological examination. Thirty eight specimens of tumour and 33 of normal colonic mucosa were collected which included 28 matched specimens of tumour and normal colon taken from a region of the gut uninvolved by tumour. The remaining specimens were six unmatched carcinoma of the colon, two normal colon mucosa, one Crohn's disease, one benign adenoma with dysplasia, two carcinoma of the caecum and one gastric carcinoma leading into the bowel. All tissues were stored at $-70^{\circ} \mathrm{C}$ until elution was performed.

\section{ELUTION OF ANTIBODIES}

A modification of the method of Boyd and James ${ }^{12}$ was used. Portions of tissue $(0 \cdot 5-5 \mathrm{~g})$ were finely chopped and washed three times in $0.01 \mathrm{M}$ phosphate buffered saline, $\mathrm{pH} 7 \cdot 2$ (PBS). Solid material was further disaggregated in nine volumes of an enzyme mixture containing $10 \mathrm{mg}$ collagenase $\mathrm{B}$ (Sigma) and $4 \mathrm{mg} \mathrm{DNase} \mathrm{(BDH)} \mathrm{in} 100 \mathrm{ml}$ PBS for $20 \mathrm{~min}$ at $37^{\circ} \mathrm{C}$ with gentle stirring. The resulting cell suspension was removed onto ice and the procedure repeated twice on any solid material. Cell suspensions were washed five times in PBS and resuspended in $5 \mathrm{ml} 15 \% \mathrm{NaCl}(\mathrm{pH} \mathrm{7.4)}$ before being incubated for two hours at $37^{\circ} \mathrm{C}$. The eluate was obtained by centrifugation at $10000 \mathrm{~g}$ for 10 minutes. The sediment was re-extracted with $15 \%$ $\mathrm{NaCl}$ as before. Resultant eluates were pooled and dialysed against $500 \mathrm{ml}$ distilled water for 24 hours with two changes of water. After centrifugation for one hour at $36000 \mathrm{~g}$, the supernatant was concentrated 10 times with polyethylene glycol and finally centrifuged for $30 \mathrm{~min}$ at $5000 \mathrm{~g}$. Eluates were stored frozen at $-20^{\circ} \mathrm{C}$. Protein estimation was by the method of Lowry with bovine serum albumin as standard.

DETECTION OF IMMUNOGLOBULINS BY ENZYMELINKED IMMUNOSORBENT ASSAY (ELISA)

The procedure was a modification of the method described by Bidwell, Bartlett, and Voller. ${ }^{13}$ The assay was done on polystyrene, flat bottomed micro titre plates (Sterilin). Wells were saturated with 50 $\mu \mathrm{l}$ of $175 \mu \mathrm{g} / \mathrm{ml}$ goat anti-human polyvalent immunoglobulins (Sigma) diluted in $0.05 \mathrm{M}$ carbonate buffer, $\mathrm{pH} 9 \cdot 6$, for four hours at $37^{\circ} \mathrm{C}$, and then overnight at $4^{\circ} \mathrm{C}$. Plates were washed three times with $0.05 \%$ Tween 20 containing $0.9 \% \mathrm{NaCl}$. Fifty microlitres of undiluted eluate was added and the plates incubated at room temperature for six to eight hours. After washing again, $50 \mu \mathrm{l}$ of goat antihuman $\operatorname{IgA}, \operatorname{IgG}$, or IgM conjugated with alkaline phosphatase (Sigma, diluted in 0.05M PBS containing $0.05 \%$ Tween 20 according to the manufacturer's instructions) was added, and the plates incubated at room temperature. Absorbance at $\mathbf{4 0 5}$ $\mathrm{nm}$ was measured with a multiscan (Titertek, Flow). In each experiment positive controls were myeloma sera specific for IgA, IgG, or IgM; negative control values were obtained from the same assay system but without the eluates (these are shown in the Table). Values greater than the mean+standard deviation of the control values were considered positive. Chi-square tests were used to determine any significant differences in the detection of immunoglobulins in normal and tumour eluates and with respect to the stage of the tumour. Wilcoxon's rank sum tests were used to compare the concentrations of each immunoglobulin present in the 28 normal and tumour eluates, and to compare immunoglobulin concentrations with respect to the stage of the tumour.

Detection of cytomegalovirus-specific immunoglobulins was done in a similar manner but with cytomegalovirus-infected cell antigen or uninfected cell antigen (see below) as the initial coating layer. Antigens were diluted from 400 to 1000 times in $0.05 \mathrm{M}$ carbonate buffer $\mathrm{pH} 9.6$ for ELISA. Each eluate was tested against control antigen and cytomegalovirus antigen because there may be antibodies in the eluates which cross react with antigens from human embryonic fibroblasts. The mean and standard deviation of eluates tested against control human embryonic fibroblast antigen allowed calculation of a positive reaction to cytomegalovirus antigen as is shown in the legend to the Table. Chi-square tests were used to determine any significant differences in the detection of cytomegalovirus-specific immunoglobulins in normal and tumour eluates, and with respect to tumour stage. There were too few eluates containing cytomegalovirus-specific immunoglobulin to compare the concentrations of immunoglobulins in normal and tumour eluates or with respect to tumour stage.

CYTOMEGALOVIRUS CELL ANTIGEN PREPARATION Human embryonic fibroblasts at pass 3 to 10 were grown in modified Eagle's medium supplemented with $10 \%$ fetal calf serum, $100 \mathrm{IU} / \mathrm{ml}$ penicillin and $200 \mu \mathrm{g} / \mathrm{ml}$ streptomycin. When confluent some cells were infected with cytomegalovirus, strain AD-169, 
Table Non-specific and cytomegalovirus-specific immunoglobulins as measured by ELISA (Optical Density) in eluates from colonic adenocarcinoma (1-34), normal colonic mucosa (1-28, 35, 36), Crohn's disease (37), benign adenoma with dysplasia (38), carcinoma of the caecum $(39,40)$ and gastric carcinoma (41). Cytomegalovirus-specific anti-complement immunofluorescence of eluates is also shown (+ positive; - negative) and their protein concentration (mg/g wet weight tissue).

\begin{tabular}{|c|c|c|c|c|c|c|c|c|c|c|c|c|c|c|c|c|c|}
\hline \multirow{3}{*}{$\begin{array}{l}\text { Patient } \\
\text { no }\end{array}$} & \multirow{3}{*}{$\begin{array}{l}\text { Duke's } \\
\text { stage }\end{array}$} & \multicolumn{8}{|c|}{ Eluates from carcinoma of colon } & \multicolumn{8}{|c|}{ Eluates from normal mucosa } \\
\hline & & \multirow{2}{*}{$\begin{array}{l}\text { Protein } \\
m g / g\end{array}$} & \multicolumn{3}{|c|}{ Non-specific } & \multicolumn{3}{|c|}{$C M V$-specific } & \multirow{2}{*}{$A C I F$} & \multirow{2}{*}{$\begin{array}{l}\text { Protein } \\
\mathrm{mg} / \mathrm{g}\end{array}$} & \multicolumn{3}{|c|}{ Non-specific } & \multicolumn{4}{|c|}{$C M V$-specific } \\
\hline & & & $\lg G$ & $\operatorname{Ig} A$ & $\operatorname{Ig} M$ & $\operatorname{Ig} G$ & $\operatorname{Ig} A$ & $\lg M$ & & & $\operatorname{Ig} G$ & $\operatorname{Ig} A$ & $\operatorname{Ig} M$ & $\operatorname{Ig} G$ & $\operatorname{Ig} A$ & $\lg M$ & $A C I F$ \\
\hline 1 & B & $0 \cdot 29$ & $\underline{0.84}$ & $\underline{1 \cdot 17}$ & $\geq 2$ & $\underline{1 \cdot 8}$ & $\underline{2.0}$ & $\underline{1.4}$ & - & $0 \cdot 78$ & $\underline{0.89}$ & $\underline{1.23}$ & $\geq 2$ & $0 \cdot 35$ & $0 \cdot 17$ & $0 \cdot 11$ & - \\
\hline 2 & $\mathrm{C}$ & 0.64 & $\overline{0.72}$ & 0.74 & $\overline{\geq 2}$ & $\geq 2$ & 0.37 & 0.4 & - & $0 \cdot 2$ & $\underline{1.03}$ & $\underline{0.85}$ & $\geq 2$ & 0.23 & 1.6 & 0.41 & - \\
\hline 3 & $\mathrm{C}$ & $0 \cdot 4$ & $\overline{0.97}$ & $\overline{0.89}$ & $\underline{1.73}$ & $\overline{\geq 2}$ & $\underline{1.41}$ & $\underline{1.82}$ & + & 0.26 & $\underline{0.98}$ & $\overline{0.25}$ & $\overline{1.85}$ & $\geq 2$ & 0.46 & $\underline{0.95}$ & + \\
\hline 4 & $\mathrm{C}$ & $0 \cdot 1$ & 0.74 & 0.77 & $\overline{1.48}$ & $\overline{0.36}$ & $\overline{0 \cdot 17}$ & $\overline{0.12}$ & - & $0 \cdot 17$ & 0.32 & 0.44 & 0.46 & $\overline{0.37}$ & 0.29 & 0.38 & - \\
\hline 5 & C & 0.09 & 0.37 & 0.42 & 1.56 & 0.57 & 0.43 & 0.35 & - & 0.58 & 0.25 & 0.43 & 0.27 & 0.45 & 0.36 & 0.28 & - \\
\hline 6 & B & 0.34 & 0.33 & $\underline{0.78}$ & 1.22 & 0.49 & 0.43 & 0.29 & - & 0.51 & 0.43 & 0.46 & 0.43 & 0.73 & 0.21 & 0.51 & - \\
\hline 7 & C & 0.42 & 0.32 & 1.81 & $\overline{0.73}$ & 0.71 & 0.26 & 0.37 & - & 0.67 & 0.39 & 0.41 & $\underline{1.45}$ & 0.21 & 0.37 & 0.39 & - \\
\hline 8 & A & 0.31 & $\underline{0.72}$ & 0.36 & $\underline{1.35}$ & 0.43 & 0.31 & 0.41 & - & 0.54 & 0.42 & 0.33 & $\overline{\geq 2}$ & 0.46 & 0.27 & 0.37 & - \\
\hline 9 & B & 0.26 & 0.77 & $\underline{0.79}$ & $\overline{0.34}$ & 0.35 & 0.25 & 0.29 & - & 0.35 & 0.38 & 0.34 & $\overline{0.37}$ & 0.44 & 0.49 & $0 \cdot 18$ & - \\
\hline 10 & C & 0.35 & $\overline{0.37}$ & $\underline{0.9}$ & $\underline{1.76}$ & 0.68 & $\underline{1.4}$ & 0.47 & - & 0.4 & 0.35 & 0.29 & 1.65 & 0.36 & 0.42 & 0.26 & - \\
\hline 11 & A & 0.42 & 1.14 & $\overline{0.41}$ & $\overline{0.32}$ & $\underline{0.89}$ & $\overline{0.4}$ & 0.37 & - & 0.76 & $\underline{0.88}$ & $\underline{0.86}$ & 1.34 & 0.41 & 0.35 & 0.24 & - \\
\hline 12 & C & 0.33 & $\overline{0.34}$ & $\underline{0.92}$ & $0 \cdot 35$ & $\overline{0.46}$ & 0.39 & 0.27 & - & $1 \cdot 2$ & $\overline{0.34}$ & $1 \cdot 18$ & 0.79 & 0.26 & 0.45 & 0.41 & - \\
\hline 13 & C & 0.42 & 0.42 & 1.49 & 0.27 & 0.27 & 0.71 & $0 \cdot 19$ & - & 1.2 & 0.27 & $\overline{0.79}$ & $\overline{1.36}$ & 0.14 & 0.36 & 0.13 & - \\
\hline 14 & C & $0 \cdot 2$ & 0.38 & 0.46 & $\underline{1.27}$ & 0.48 & 0.34 & 0.35 & - & 0.52 & 0.26 & $\underline{0.79}$ & $\overline{0.37}$ & 0.69 & 0.23 & $0 \cdot 18$ & - \\
\hline 15 & C & 0.38 & 0.44 & $\underline{0.89}$ & $\overline{0.36}$ & 0.2 & $\underline{0.89}$ & 0.27 & - & 0.45 & 0.24 & 1.52 & $\underline{0.78}$ & 0.38 & 0.19 & 0.46 & - \\
\hline 16 & C & 0.07 & 0.36 & $\overline{0.35}$ & $0 \cdot 29$ & 0.44 & $\overline{0.28}$ & 0.49 & - & 0.7 & 0.44 & $\overline{0.43}$ & $\overline{0.47}$ & 0.53 & 0.62 & 0.26 & - \\
\hline 17 & B & $0 \cdot 14$ & 0.35 & 0.45 & 0.27 & $0 \cdot 31$ & 0.57 & 0.26 & - & $1 \cdot 1$ & 0.4 & $\underline{0.98}$ & $\underline{1.23}$ & 0.43 & 0.56 & $0 \cdot 18$ & - \\
\hline 18 & A & 0.06 & 0.27 & 0.36 & 0.47 & $0 \cdot 24$ & 0.23 & 0.6 & - & 0.4 & 0.45 & 0.87 & 1.39 & 0.46 & 0.32 & 0.29 & - \\
\hline 19 & C & 0.39 & 0.37 & 0.44 & 0.46 & 0.41 & $0 \cdot 16$ & $0 \cdot 15$ & - & $0 \cdot 2$ & 0.39 & $\overline{0.47}$ & $\overline{0.46}$ & 0.73 & 0.77 & 0.61 & - \\
\hline 20 & A & 0.22 & 0.46 & 0.35 & $0 \cdot 38$ & 0.47 & 0.28 & $0 \cdot 18$ & - & 0.31 & 0.42 & $\underline{0.87}$ & $\underline{1.83}$ & 0.49 & 0.42 & 0.25 & - \\
\hline 21 & B & $0 \cdot 18$ & 0.36 & 0.4 & 0.43 & $0 \cdot 28$ & 0.15 & 0.47 & - & 0.29 & $0 \cdot 38$ & 1.08 & $\underline{1.5}$ & 0.41 & 0.37 & 0.28 & - \\
\hline 22 & B & 0.08 & 0.28 & 0.42 & 0.38 & 0.23 & $0 \cdot 14$ & 0.39 & - & 0.29 & 0.44 & $\underline{0.85}$ & 1.43 & 0.34 & 0.45 & 0.21 & - \\
\hline 23 & B & $0 \cdot 18$ & 0.4 & 0.37 & 0.42 & 0.41 & 0.17 & 0.12 & - & 0.39 & $\underline{1.06}$ & $\overline{0.8}$ & $\overline{0.38}$ & $0 \cdot 16$ & 0.36 & 0.44 & - \\
\hline 24 & B & $0 \cdot 1$ & 0.44 & 0.31 & 0.49 & $0 \cdot 21$ & $0 \cdot 12$ & 0.48 & - & 0.27 & 0.39 & 0.39 & 0.37 & 0.25 & 0.29 & 0.3 & - \\
\hline 25 & C & $0 \cdot 15$ & 0.42 & 0.38 & 0.45 & 0.29 & 0.37 & 0.22 & - & 0.05 & 0.45 & 0.37 & 0.39 & 0.28 & 0.34 & 0.26 & - \\
\hline 26 & C & 0.34 & 0.31 & 0.42 & 0.5 & 0.64 & $0 \cdot 28$ & 0.33 & - & 0.63 & 0.43 & $\underline{1.01}$ & 0.41 & 0.23 & 0.29 & 0.37 & - \\
\hline 27 & B & 0.03 & 0.44 & 0.45 & 0.35 & 0.56 & 0.72 & $0 \cdot 18$ & - & 1.09 & $0 \cdot 38$ & 0.87 & $\geq 2$ & 0.4 & 1.42 & $\underline{1.17}$ & - \\
\hline 28 & B & $0 \cdot 3$ & 0.32 & 0.46 & 0.36 & $0 \cdot 29$ & 0.42 & 0.26 & - & 0.42 & 0.29 & 0.25 & 0.49 & 0.22 & $\overline{0.29}$ & $\overline{0.28}$ & - \\
\hline 29 & B & 0.26 & 0.26 & 0.41 & 0.42 & $0 \cdot 15$ & 0.19 & 0.19 & - & & & & & & & & \\
\hline 30 & C & 1.02 & 0.32 & 0.36 & 0.41 & 0.24 & $0 \cdot 16$ & 0.39 & - & & & & & & & & \\
\hline 31 & B & $0 \cdot 12$ & 0.45 & 0.44 & 0.22 & $0 \cdot 18$ & 0.12 & 0.56 & - & & & & & & & & \\
\hline 32 & C & $0 \cdot 36$ & 0.35 & $\underline{0.94}$ & 1.42 & 0.47 & 0.43 & 0.36 & - & & & & & & & & \\
\hline 33 & B & 0.32 & 0.46 & 0.36 & $\overline{1.71}$ & 0.49 & 0.49 & 0.15 & - & & & & & & & & \\
\hline 34 & B & 0.38 & 0.47 & 0.29 & $\overline{0.36}$ & 0.31 & $0 \cdot 17$ & 0.17 & - & & & & & & & & \\
\hline 35 & & & & & & & & & & 1.22 & $\underline{0.97}$ & $\underline{0.91}$ & $\geq 2$ & $0 \cdot 19$ & 0.41 & 0.42 & - \\
\hline 36 & & & & & & & & & & 0.31 & $\underline{0.89}$ & 0.87 & $\overline{0.37}$ & 1.04 & 0.96 & 0.37 & - \\
\hline 37 & & & & & & & & & & $0 \cdot 18$ & $\overline{0.35}$ & $\overline{0.34}$ & 0.29 & $\overline{0.56}$ & $\overline{0.24}$ & 0.22 & - \\
\hline 38 & & 0.5 & 0.24 & $\underline{0.87}$ & $\underline{0.98}$ & $0 \cdot 14$ & 0.42 & 0.37 & - & 0.63 & $\underline{1.08}$ & 0.86 & 0.32 & 0.24 & 0.27 & 0.15 & - \\
\hline 39 & & 0.27 & 0.25 & $\overline{0.36}$ & $\overline{0.44}$ & $0 \cdot 26$ & 0.41 & 0.22 & - & & & & & & & & \\
\hline 40 & & 0.09 & $\underline{0.93}$ & 0.87 & $\underline{1.55}$ & $\underline{1.48}$ & 0.39 & 0.26 & - & & & & & & & & \\
\hline 41 & & 0.23 & $\overline{0.34}$ & $\overline{0.86}$ & $\overline{0.49}$ & $\overline{0.21}$ & 0.13 & 0.24 & - & 1.6 & 0.32 & 0.42 & $\underline{0.95}$ & $0 \cdot 18$ & 0.11 & $\underline{0.96}$ & - \\
\hline
\end{tabular}

Control values for non-specific antibodies: IgG mean 0.42 standard deviation 0.06 IgA mean 0.39 standard deviation 0.09 IgM mean 0.43 standard deviation 0.07

Control values for CMV-specific antibodies: IgG mean 0.52 standard deviation 0.22 IgA mean 0.54 standard deviation $0 \cdot 25$ IgM mean 0.44 standard deviation 0.18

Values greater than the mean + standard deviation were considered positive; these values are underlined.

at 1-2 plaque-forming units per cell. Infected and uninfected cultures were maintained in medium containing $2 \%$ fetal calf serum at $37^{\circ} \mathrm{C}$ until advanced cytopathic effects were observed in the infected culture. The monolayers were washed with cold PBS and harvested using glass beads. Cells $\left(5 \times 10^{6}\right)$ were washed three times in PBS and resuspended in $1 \mathrm{ml}$ glycine buffer ( 5 parts $0.1 \mathrm{M}$ 
glycine plus 3 parts $0 \cdot 1 \mathrm{M} \mathrm{NaOH}$, prepared on day of use). They were sonicated for two minutes at $9 \mathrm{kc} / \mathrm{s}$ and stored at $-70^{\circ} \mathrm{C}$ until required.

CYTOMEGALOVIRUS-SPECIFIC ANTI-COMPLEMENT IMMUNOFLUORESCENCE TEST

Monolayers of human embryonic fibroblast cells grown on cover slips were infected with cytomegalovirus, strain $A D-169$, and 48 h later were fixed in cold acetone for 10 minutes. Anticomplement immunofluorescence (ACIF) was carried out by the method of Hart et al. ${ }^{8}$

\section{Results}

Normal colonic mucosa and slices of adenocarcinomas were disaggregated with collagenase and DNase, and 71 eluates prepared from the resultant single cell suspension after treatment with $15 \%$ $\mathrm{NaCl}$. Protein concentrations of eluates ranged from $0.07-1 \mathrm{mg} / \mathrm{ml}$, mean value $0.48 \mathrm{mg} / \mathrm{ml}$; for carcinoma eluates a mean value of $0 \cdot 28 \pm 0 \cdot 19$ (standard deviation) $\mathrm{mg} / \mathrm{g}$ of tissue, and for normal eluates $0.57 \pm 0.37$ (standard deviation) $\mathrm{mg} / \mathrm{g}$ of tissue were found.

Using ELISA, out of 38 specimens of tumour, IgG was detected in eight eluates, IgA in 15 and IgM in 14 (Table). Out of 33 specimens of normal colon, IgG was detected in eight eluates, $\operatorname{IgA}$ in 18 and IgM in 18.

These results indicate that there is no significant difference in the detection of IgG (24\%), IgA (55\%) and IgM $(55 \%)$ in normal eluates compared with tumour eluates ( $21 \%$ contained IgG, $39 \%$ contained IgA and $37 \%$ contained $\operatorname{IgM}(0 \cdot 1<\mathrm{p}<0 \cdot 5))$. There were no significant differences in the immunoglobulin concentrations of normal and tumour eluates. When the 28 matched pairs of normal and tumour eluates from the same patient were compared (shown in the Table, patients 1-28), five normal and seven tumour eluates contained IgG, 15 normal and 11 tumour eluates contained $\operatorname{IgA}$, and 15 normal and 10 tumour eluates contained IgM. These results also indicate that there is no significant difference in the detection of $\operatorname{IgG}, \operatorname{IgA}$ and $\operatorname{IgM}$ in the 28 matched eluates. In three pairs of specimens the same immunoglobulin types were present in both the normal and tumour eluates, and in five matched cases no immunoglobulins were detected in eluates from either normal or tumour tissues.

Cytomegalovirus-specific antibody as measured by ELISA was found in seven of 38 tumour eluates and five of 33 normal colon eluates (also shown in the Table). Comparing the 28 matched specimens, cytomegalovirus-specific IgG was de- tected in one normal and four tumour eluates, cytomegalovirus-specific $\operatorname{IgA}$ in two normal and four tumour eluates and cytomegalovirus-specific IgM in two normal and two tumour eluates. These results show no significant difference in the presence of cytomegalovirus-specific $\operatorname{IgG}, \operatorname{IgA}$ and $\operatorname{IgM}$ in tumour eluates as compared with normal eluates $(0 \cdot 1<\mathrm{p}<0 \cdot 5)$. In two instances, cytomegalovirusspecific immunoglobulins were present in the eluates from both the tumour and normal tissue of the same patient, although of the same broad immunoglobulin class in only one.

The patients from whom the specimens were obtained had colorectal adenocarcinoma for the most part, and were grouped histologically according to the Duke's system of classification; a few had other bowel disorders (Table). Four out of 34 patients with colonic carcinoma had Duke's stage A, 14 of 34 had stage $B$, and 16 of 34 had stage C. Of the patients with stage A disease, two of four carcinoma eluates contained detectable immunoglobulin; this was IgG in both cases and in one case $\operatorname{IgA}$ was also present. Four of 14 carcinoma eluates from patients with Duke's stage B were positive for immunoglobulin; IgG was present in two eluates, IgA in three eluates and IgM in three eluates. Eleven of 16 eluates from patients with stage $C$ disease contained immunoglobulin; IgG was present in three eluates, IgA in nine eluates and IgM in eight eluates. These results show no significant differences in the detection of IgG (19\%) $(\mathrm{p}>0.5)$, $\operatorname{IgA}(56 \%) \quad(0.05<\mathrm{p}<0.1)$ and $\operatorname{IgM}(50 \%)$ $(0.1<\mathrm{p}<0.5)$ in eluates from patients with stage $\mathrm{C}$ disease compared with stage B disease (IgG was detected in $14 \%$ and $\operatorname{IgA}$ and IgM were detected in $21 \%$ eluates). No significant differences in the immunoglobulin concentrations were found with respect to tumour stage.

Cytomegalovirus-specific immunoglobulin was detected in one patient with Duke's stage A, one patient with stage B and four patients with stage C. There is no significant increase in the detection of cytomegalovirus-immunoglobulin in eluates from patients with stage $\mathrm{C}$ tumour $(25 \%)$ compared to stage B tumour $(7 \%)(0 \cdot 1<p<0.5)$.

Anti-complement immunofluorescence was performed using human embryonic fibroblast cells infected with cytomegalovirus, strain $\mathrm{AD}-169$, and uninfected human embryonic fibroblasts as controls. Eluates prepared from both normal and tumour tissue of patient number three showed positive immunofluorescence.

Although the eluates from the colonic tissues contained varied amounts of protein, the nature of these, apart from IgA, IgG, IgM and cytomegalovirus-specific immunoglobulins was not determined. 


\section{Discussion}

Elution of bound immunoglobulin from normal colonic mucosa and colorectal carcinoma was achieved by high salt extraction. There were no significant differences in the detection of IgG, IgA and IgM in normal and carcinoma eluates: IgG was present in $24 \%$ of normal mucosa eluates and $21 \%$ of carcinoma eluates $(p>0.5): \operatorname{IgA}$ was present in $55 \%$ of normal eluates and $39 \%$ of carcinoma eluates $(0 \cdot 1<\mathrm{p}<0 \cdot 5)$ : IgM was present in $55 \%$ of normal eluates and $37 \%$ of carcinoma eluates $(0 \cdot 1<\mathrm{p}<0.5)$. Detection of $\operatorname{IgG}, \operatorname{IgA}, \operatorname{IgM}$ and cytomegalovirus-specific immunoglobulin was not significantly different in eluates from patients with Duke's stage C compared with eluates from stage B disease.

MacSween and Eastwood ${ }^{14}$ found significantly higher concentrations of IgG in eluates of colonic carcinoma with regional metastasis than in eluates of localised tumours. This difference was not apparent in eluates of corresponding normal tissue, and they suggested that the increase in IgG was associated with the metastatic state. Also it has been proposed that patients with colorectal carcinoma who initially have higher serum levels of $\operatorname{IgG}$ and perhaps of $\operatorname{IgA}$ may have a longer relapse free survival. ${ }^{15}$ More recently, all tumours have been reported to contain IgG and IgA, whereas only $40 \%$ contained measurable amounts of IgM. ${ }^{16}$ These differences in immunoglobulin detection from the present study may reflect use of different or larger specimens from patients or differences in the preparation of eluates. In addition the ELISA used here employed polyvalent antiserum as the first layer which may have resulted in competition for immunoglobulin binding sites and therefore reduced detection of individual immunoglobulins. Jones $e t$ al $^{16}$ found less IgA, IgM and $\mathrm{IgG}$ in eluates from colorectal carcinoma than in normal colonic mucosa. Also there was no association between immunoglobulin and the amount of tumour tissue, necrosis, mucin production and staging, although it was suggested that tumour associated IgM accompanied an unfavourable prognosis. In the present study detection of $\operatorname{IgG}, \operatorname{IgA}$, IgM and cytomegalovirus specific immunoglobulin was not significantly different in stage $\mathrm{C}$ disease compared with stage B. Further interpretation of an association between immunoglobulins and staging is prevented by the small number of eluates from patients with stage A tumour.

There were no significant differences in the detection of cytomegalovirus specific IgG, IgA and IgM in the 28 matched samples. The presence of cytomegalovirus specific immunoglobulin in normal and tumour eluates suggests that some cells in the colonic mucosa may be expressing cytomegalovirus specific antigens on their surfaces to which the antibodies are binding. It also implies that such antigens will be blocked and thus escape detection by such techniques as immunofluorescence. It is of interest in this context that Roche et al, ${ }^{9}$ while showing cytomegalovirus DNA in various colonic diseases by hybridisation, were unable to show cytomegalovirus antigens by immunofluorescence. Only two eluates in our series were positive for cytomegalovirus antibodies using anticomplement immunofluorescence of AD-169 infected fibroblasts which almost certainly reflects the greater sensitivity of the ELISA method over anticomplement immunofluorescence.

The presence of cytomegalovirus immunoglobulins in eluates from both normal and tumour material suggests that cytomegalovirus infection is not associated specifically with colonic adenocarcinomas. Furthermore, in two cases, such antibodies were detected in eluates from tumour and normal colonic mucosa of the same patient. A distinction was not made between antibody eluted from infiltrating lymphocytes or from epithelial cells in the adenocarcinomatous tissue and the normal colonic mucosa. Immunofluorescence on sections of colon may resolve this, although recent evidence from virus isolation and nucleic acid hybridisation would indicate that the presence of the virus, at least, is not solely because of infiltrating mononuclear cells infected with cytomegalovirus. ${ }^{9}$

It is known that, after a primary infection, cytomegalovirus persists in a latent form within man. ${ }^{1}$ As a number of studies has shown the presence of cytomegalovirus in the gastrointestinal tract either in normal patients, those with chronic diseases such as ulcerative colitis, ${ }^{17}$ or in colorectal adenocarcinoma, ${ }^{5}$ the gastrointestinal tract has been suggested as a possible site of latency of cytomegalovirus. ${ }^{9}$ The present study, thus, would also indicate that cytomegalovirus is found in normal colonic and adenocarcinoma cells by the detection of cytomegalovirus specific immunoglobulins in tissue eluates from some patients. It cannot be discounted, however, that some proportion of these cytomegalovirus antibodies may be sticking non-specifically. Further work is necessary to establish whether cytomegalovirus is associated with transformation of normal cells to the malignant state in the colon, whether it is the initiating factor or a cofactor, or whether it is not involved at all in this process.

We wish to acknowledge the very kind help of $\mathrm{Mr}$ I MacLeod of the Royal Infirmary, Edinburgh, and Dr H Gilmour of the Department of Pathology, 
University of Edinburgh. This work was supported by the Cancer Research Campaign.

\section{References}

1 Weller TH. The cytomegaloviruses: ubiquitous agents with protean clinical manifestations. $N$ Engl $J$ Med 1971; 285: 203-14, 267-74.

2 Giraldo G, Beth E, Huang E-S. Kaposi's sarcoma and its relationship to cytomegalovirus (CMV) II. CMV DNA and CMV early antigens in Kaposi's sarcoma. Int J Cancer 1980; 26: 23-9.

3 Melnick J, Lewis R, Wimberly I, Kaufman R, Adam E. Association of cytomegalovirus (CMV) infection with cervical cancer: isolation of CMV from cell cultures derived from cervical biopsy. Intervirology 1978; 10: 115-9.

4 Geder L, Sanford EJ, Rohner TJ, Rapp F. Cytomegalovirus and cancer of the prostate; in vitro transformation of human cells. Cancer Treat Rep 1977; 61: 139-46.

5 Huang E-S, Roche JK. Cytomegalovirus DNA and adenocarcinoma of the colon: evidence for latent viral infection. Lancet 1978; 1: 957-60.

6 Hashiro GM, Horikami S, Loh PC. Cytomegalovirus isolations from cell cultures of human adenocarcinomas of the colon. Intervirology 1979; 12: 84-8.

7 Brichacek B, Hirsch I, Zavadova H, Prochazka M, Faltyn J, Vonka K. Absence of cytomegalovirus DNA from adenocarcinoma of the colon. Intervirology 1980; 14: 223-7.
8 Hart H, Neill W, Norval M. Lack of association of cytomegalovirus with adenocarcinoma of the colon. Gut 1982; 23: 21-30.

9 Roche JK, Cheung K-S, Boldogh I, Huang E-S, Lang DJ. Cytomegalovirus: detection in human colonic and circulating mononuclear cells in association with gastrointestinal disease. Int J Cancer 1981; 27: 659-67.

10 Avni A, Haikin H, Feuchtwanger MM, Sacks M, Naggan L, Sarov B, Sarov I. Antibody pattern to human cytomegalovirus in patients with adenocarcinoma of the colon. Intervirology 1981; 16: 244-9.

11 Seth P, Balachandran N. Elution of herpes simplex virus-specific cytotoxic antibodies from squamous cell carcinoma of uterine cervix. Nature 1980; 286: 613-5.

12 Boyd JE, James K. Antibodies to tumour eluates react preferentially with non-lymphoid tumours. Cancer Immunol Immunother 1983; 15: 54-8.

13 Bidwell DE, Bartlett A, Voller A. Enzyme immunoassays for viral diseases. $J$ Infect Dis 1977; 135: suppl. 274-8.

14 MacSween JM, EastwoodJL. Immunoglobulins associated with human tumours in vivo: IgG concentrations in eluates of colonic carcinomas. Br J Cancer 1980; 42: 503-9.

15 Panettiere FJ. IgA antibodies and prognosis in colorectal cancer (letter). Int J Cancer 1981; 27: 865.

16 Jones SL, Pihl E, Cuthbertson AM, Hughes ESR, Johnson WR, Rollo AJ. Immunoglobulins intrinsic to colorectal carcinoma: an unfavourable prognostic association with IgM. J Natl Cancer Inst 1983; 71: 469-72.

17 Sidi S, Graham JH, Razvi SA, Banks PA. Cytomegalovirus infection of the colon associated with ulcerative colitis. Arch Surg 1979; 114: 857-9. 